\title{
Potential immune of recombinant serine protease of Corynebacterium pseudotuberculosis
}

\author{
Daniela Droppa Almeida', Wanessa Lordelo Vivas', Judson Wallace Rodrigues da Silva', \\ Caroline de Santana Ferreira ${ }^{*}$, Katharina Kelly Oliveira', Ioná Brito², Fernando Mendonça Diz ${ }^{1}$, Sibele Borsuk ${ }^{3}$, \\ Isabel Bezerra Lima-Verde ${ }^{1}$, Vasco Azevedo ${ }^{4}$, Roberto Meyer ${ }^{5}$, Francine Ferreira Padilha ${ }^{1}$ \\ From 5th Congress of the Brazilian Biotechnology Society (SBBIOTEC) \\ Florianópolis, Brazil. 10-14 November 2013
}

\section{Background}

Caseous lymphadenitis (CLA) has high relevance. It is a chronic disease that affects sheep and goats. The causative agent is Corynebacterium pseudotuberculosis, facultative intracellular bacteria. The prevalence of caseous lymphadenitis is high in many regions of the world, including South America. Brazil has 78\% of seroprevalence in goats $[1,2]$. Therefore, prophylaxis becomes the best strategy as an effective vaccine able to eradicate disease, but also to formulate a serologic test able to detect visceral cases. One of the first steps for developing of a serological test and an effective vaccine is the choice of a target, which must present appropriate antigenic characteristics. The CP40 protein (corynebacterial protease 40 ) have been studied in several studies. This protease is considered one of the virulence factors of C. pseudotuberculosis. Encoded by the gene $\mathrm{CP} 40$ and characterized as a serine protease, proteins responsible for several functions, such as providing the activation of pro-inflammatory citocines which will help in the activation of the immune response. However the aim of this study was to evaluate the potential immune serine protease recombinant in $\mathrm{BALB} / \mathrm{c}$ mice.

\section{Methods}

To this end, CP40 protein was expressed in a heterologous genes in a prokaryotic system and purified by nickel affinity chromatography. The antigenicity of $\mathrm{rCP} 40$ was determined through positive and negative sera from animals for LC by Western Blotting. To determine immunogenicity, BALB / c mice were inoculated with a solution of rCP40, saponin and Freund's adjuvants in three doses on days 0 , 15 and 30 . The serum samples of these animals were collected to check the production of specific antibodies rCP40. Statistical analysis was performed using GraphPad Prism version 6.0 for Windows (GraphPad Software, San Diego, CA).

\section{Results and conclusions}

Positive sera reacted with the recombinant protein, demonstrating that $\mathrm{rCP} 40$ maintained the antigenic properties, which is important because it demonstrates that antibodies generated against the native protein present in the bactéria C. pseutuberculosis were able to recognize the recombinant protein. The results of the ELISA showed that the development of humoral immune response was generated by the experimental groups were inoculated with rCP40 associated with both adjuvants. The activation of helper $\mathrm{T}$ cells express ligands. Cytokines induce isotype switching of immunoglobulins [3] which are fixed more firmly to the antigens and plays diverse functions, forming the most effective mediators of humoral response by involving the cellular immune system, including phagocytosis and complement proteins. In mice the role of CD4+ $\mathrm{T}$-cells helper can provide production class antibody IgG2a and IgG2B that are capable of promoting directly or indirectly a response from Th1 and lead to opsonization and toxicity mediated by cells [4].

\section{Authors' details \\ 'Universidade Tiradentes - Unit, Aracaju, Brazil. ${ }^{2}$ Universidade Estadual do Ceará, Fortaleza, Brazil. ${ }^{3}$ Universidade Federal de Pelotas - UFPel, Pelotas, Brazil. "Universidade Federal de Minas Gerais - UFMG, Belo Horizonte, Brazil. ${ }^{5}$ Universidade Federal da Bahia - UFBA, Salvador, Brazil.}

Published: 1 October 2014

${ }^{1}$ Universidade Tiradentes - Unit, Aracaju, Brazil

Full list of author information is available at the end of the article 


\section{References}

1. Seyffert N, Guimarães AS, Pacheco LGC, Portela RW, Bastos BL, Dorella FA, Heinemann MB, Lage AP, Gouveia AMG, Meyer R, Miyoshi A, Azevedo V: High seroprevalence of caseous lymphadenitis in Brazilian goat herds revealed by Corynebacterium pseudotuberculosis secreted proteinsbased ELISA. Research in Veterinary Science 88(1):50-55, February 2010.

2. Pavan ME, Robles C, Cairó FM, Marcellino R, Pettinari MJ: Identification of Corynebacterium pseudotuberculosis from sheep by PCR-restriction analysis using the RNA polymerase $\beta$-subunit gene (rpoB). 2012 Research in Veterinary Science 92, 2: 202-206.

3. Adame-Gallegos JR, Shi J, Mcintosh RS, Pleass RJ: The generation and evaluation of two panels of epitope-matched mouse $\lg G 1$, $\lg G 2 a, \lg G 2 b$ and lgG3 antibodies specific for Plasmodium falciparum and

Plasmodium yoelii merozoite surface protein 1-19 (MSP119). Experimental Parasitology 2012, 130:384-393.

4. Hartmann W, Eschbach M-L, Breloer M: Strongyloides ratti infection modulates $B$ and $T$ cell responses to third party antigens. Experimental Parasitology 2012, 132:69-75.

doi:10.1186/1753-6561-8-S4-P143

Cite this article as: Almeida et al:: Potential immune of recombinant serine protease of Corynebacterium pseudotuberculosis. BMC Proceedings 2014 8(Suppl 4):P143.

\section{Submit your next manuscript to BioMed Central} and take full advantage of:

- Convenient online submission

- Thorough peer review

- No space constraints or color figure charges

- Immediate publication on acceptance

- Inclusion in PubMed, CAS, Scopus and Google Scholar

- Research which is freely available for redistribution

Submit your manuscript at www.biomedcentral.com/submit 